\title{
Electrodeposition of Platinum and Ruthenium Nanoparticles in Multiwalled Carbon Nanotube-Nafion Nanocomposite for Methanol Electrooxidation
}

\author{
Yu-Huei Hong and Yu-Chen Tsai \\ Department of Chemical Engineering, National Chung Hsing University, 250 Kuo Kuang Road, Taichung 40227, Taiwan \\ Correspondence should be addressed to Yu-Chen Tsai, yctsai@dragon.nchu.edu.tw
}

Received 27 May 2009; Accepted 25 August 2009

Recommended by Zhi-Li Xiao

PtRu nanoparticles with a diameter of $10-15 \mathrm{~nm}$ were electrodeposited within multiwalled carbon nanotube-Nafion (MWCNTNafion) nanocomposite. The formation of PtRu nanoparticles in MWCNT-Nafion nanocomposite was characterized by scanning electron microscopy, transmission electron microscopy, and energy dispersive X-ray spectroscopy. The electrocatalytic activity towards the methanol electrooxidation at PtRu-MWCNT-Nafion and Pt-MWCNT-Nafion nanocomposite-modified glassy carbon electrodes was investigated by cyclic voltammetry. The results indicated that the PtRu-MWCNT-Nafion nanocomposite was electrocatalytically more active than Pt-MWCNT-Nafion nanocomposite. The effect of atomic ratio of Pt : Ru on the electrocatalytic ability towards the methanol electrooxidation was investigated in order to achieve a high catalyst use. The PtRu bimetallic catalyst with $1: 1$ atomic ratio showed better electrocatalytic activity towards the methanol electrooxidation. The stability for the methanol electrooxidation at PtRu-MWCNT-Nafion nanocomposite modified was also investigated.

Copyright ( 2009 Y.-H. Hong and Y.-C. Tsai. This is an open access article distributed under the Creative Commons Attribution License, which permits unrestricted use, distribution, and reproduction in any medium, provided the original work is properly cited.

\section{Introduction}

Direct methanol fuel cell is an attractive power source for portable power applications and in electrical vehicles [1]. The anodic oxidation of methanol on electrode surfaces in acidic electrolytes is a catalytic reaction, in which the $\mathrm{CO}_{2}$ and six electrons were produced. The main factors that limit the practical application of direct methanol fuel cell are the sluggish kinetics of methanol electrooxidation at anode and the poisoning of electrode surfaces. Therefore, the development of highly effective methanol electrooxidation catalysts seems very attractive. Pt shows a good electrocatalytic activity towards the methanol electrooxidation; however, it is easily poisoned by $\mathrm{CO}$, the intermediates of methanol electrooxidation. Much effort has been made to develop Pt-based catalysts with higher CO poisoning tolerance and electrocatalytic activity. Improved electrocatalytic activity towards the methanol electrooxidation has been reported for Pt-based catalysts with other elements such as Ru [2], Sn $[3]$, and Os $[4,5]$. Among these Pt-based catalysts, PtRu bimetallic catalyst has shown the best electrocatalytic activity towards the methanol electrooxidation. The improvement of electrocatalytic activity towards the methanol electrooxidation with PtRu catalyst can be ascribed to the bifunctional mechanism. The CO removal process is achieved at $\mathrm{PtRu}$ catalyst because of the reaction of $\mathrm{Ru}-\mathrm{OH}$ groups with neighboring $\mathrm{CO}$ adsorbed on $\mathrm{Pt}[1]$.

Metal nanoparticles possess a high catalytic efficiency and a large surface-to-volume ratio [6-12]. A large variety of methods including impregnation [13], colloidal deposition [14], supercritical fluid [15], and electrodeposition [16] have been reported for the synthesis of PtRu nanoparticles. The electrochemical route is an effective procedure when compared with others which are complexity of the fabrication steps and impurity might be involved during the preparation. The synthesis of PtRu nanoparticles on a suitable catalyst support which provides dispersion and stability is important in the field of direct methanol fuel cell. In recent studies, carbon nanotubes (CNTs) have been considered as a promising material for catalyst support because of their good electrical 
conductivity, high chemical stability, and large surface-to volume ratio [17]. The applications of CNTs in fuel cells as a catalyst support have been reported in literature [18-20].

Nafion has been used as a medium for dispersion of CNTs in aqueous solution $[21,22]$. By the combination of multiwalled carbon nanotube (MWCNTs) and Nafion, a stable electroanalytical nanocomposite film of MWCNTNafion can be prepared by a simple solvent casting process. MWCNT-Nafion-modified glassy carbon electrodes have been applied to electroanalytical applications [23, 24]. The aim of this study is to electrodeposite PtRu nanoparticles in MWCNT-Nafion nanocomposite in order to improve its electrocatalytic behavior for the methanol electrooxidation. The effect of the atomic composition of PtRu on the electrocatalytic ability towards the electrochemical oxidation of methanol is investigated and discussed.

\section{Experimental}

2.1. Reagents. $\mathrm{K}_{2} \mathrm{PtCl}_{6}$ was obtained from Acros. Ruthenium(III) chloride hydrate and methanol were supplied by Sigma. Nafion ( $5 \mathrm{wt} \%$ in lower aliphatic alcohol) was purchased from Aldrich. Sulfuric acid was obtained from Fluka. The MWCNTs (TECO Nanotech Co., Ltd., Taiwan) used in this study were of $\sim 99 \%$ purity and synthesized by an electric arc discharge method. The reagents were used as purchased without further pretreatment. In this study, all solutions were prepared with deionized water of resistivity not less than $18 \mathrm{M} \Omega \mathrm{cm}$ taken from a Milli-Q water purification system (Milli-Q, USA).

2.2. Apparatus. Electrochemical experiments were performed with an Autolabe PGSTA30 Electrochemical Analyzer (Eco Chemie, Netherlands). A conventional threeelectrode system was carried out with a glassy carbon working electrode ( $3 \mathrm{~mm}$ diameter), a platinum wire counter electrode, and an $\mathrm{Ag} / \mathrm{AgCl}(3 \mathrm{M} \mathrm{KCl})$ reference electrode (all Metrohm., Switzerland). Scanning electron microscopy (SEM) images were obtained on a JSM-6700F (JEOL, Japan). Transmission electron microscopy (TEM) images were obtained using a JEM-2010 (JEOL, Japan).

\subsection{Preparation of PtRu-MWCNT-Nafion Nanocomposite-} Modified Glassy Carbon Electrodes. A $0.5 \mathrm{wt} \%$ Nafion solution was prepared by diluting $5 \mathrm{wt} \%$ Nafion solution with $0.1 \mathrm{M}$ phosphate buffer solution ( $\mathrm{pH} 7$ ). A $10 \mathrm{mg}$ MWCNTs were added to $1 \mathrm{~mL} 0.5 \mathrm{wt} \%$ Nafion solution with the aid of ultrasonic agitation for 1 hour to form a homogeneous MWCNT-Nafion solution. The glassy carbon electrode was polished with 0.3 and $0.05 \mu \mathrm{m}$ alumina slurry and was rinsed with deionized water before modification. The MWCNTNafion nanocomposite film-modified glassy carbon electrode was prepared by casting a $6 \mu \mathrm{L}$ of MWCNT-Nafion solution onto the surface of a glassy carbon electrode and drying under room temperature in the air. The PtRu nanoparticles were electrodeposited within the MWCNTNafion nanocomposite in a $0.1 \mathrm{M}$ phosphate buffer solution $(\mathrm{pH} 7)$ containing different concentrations of $\mathrm{K}_{2} \mathrm{PtCl}_{6}$ and

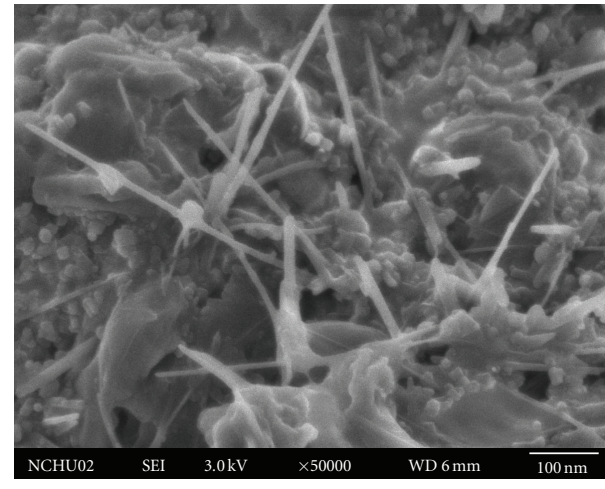

(a)

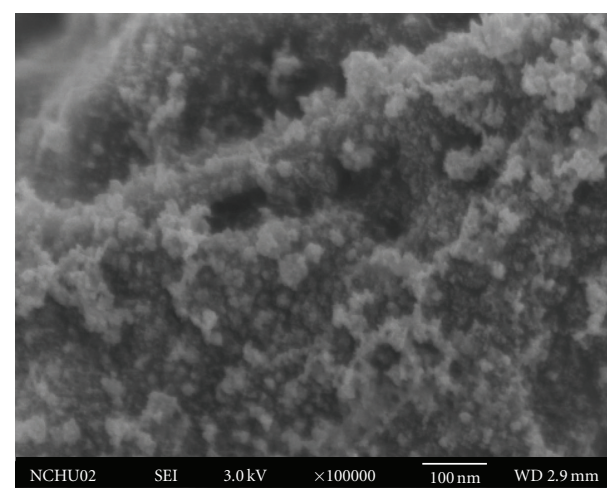

(b)

FIGURE 1: SEM images of MWCNT-Nafion nanocomposites before (a) and after (b) electrodeposition of PtRu nanoparticles.

$\mathrm{RuCl}_{3}$ by cyclic voltammetry ranging from -1.0 to $0 \mathrm{~V}$ versus $\mathrm{Ag} / \mathrm{AgCl}$ at a scan rate of $50 \mathrm{mV} \mathrm{s}^{-1}$ for 7 cycles. The atomic compositions of the $\mathrm{PtRu}$ nanoparticles electrodeposited in MWCNT-Nafion nanocomposite were analyzed by an energy-dispersive X-ray spectrometer. The content of PtRu in the MWCNT-Nafion nanocomposite was ca. $14 \mathrm{wt} \%$ which was determined by thermogravimetric analysis (not shown).

\section{Results and Discussion}

3.1. Characterization of PtRu nanoparticles with SEM, TEM, and Energy-Dispersive X-Ray Spectroscopy (EDS). The electrodeposition of PtRu nanoparticles in MWCNT-Nafion nanocomposite was investigated by SEM and TEM and EDS was used to confirm the PtRu composition of the deposits. Figure 1 shows the SEM images of MWCNT-Nafion nanocomposite before and after electrodeposition of PtRu nanoparticles. The MWCNTs were well dispersed in the MWCNT-Nafion matrix that can be seen in Figure 1(a). This means that Nafion is a suitable medium for the dispersion of MWCNTs and MWCNTs act as high conductivity nanowires throughout the MWCNT-Nafion nanocomposite. The electrodeposited PtRu nanoparticles were observed on the surface of MWCNTs (see Figure 1(b)). Further information of the PtRu nanoparticles on the surface of MWCNTs was investigated by TEM. Figure 2 shows the typical TEM 


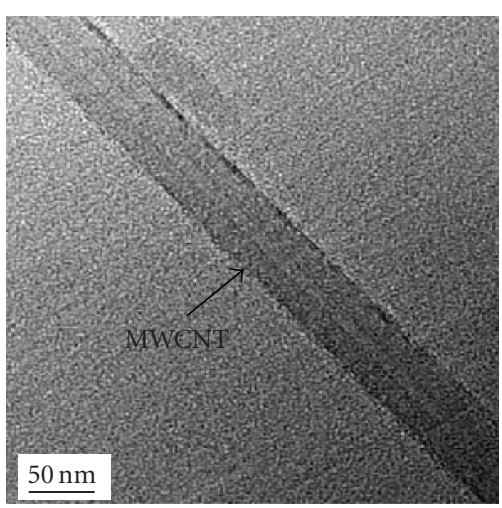

(a)

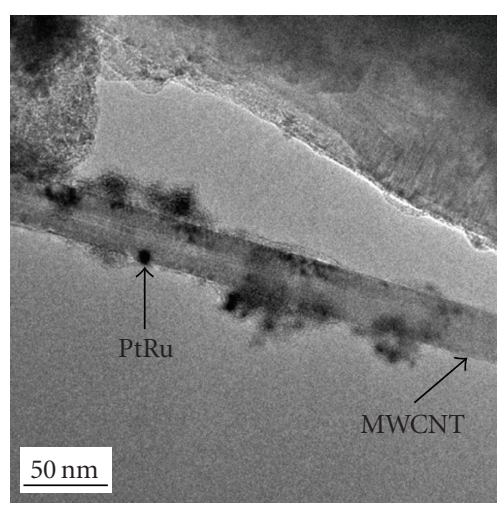

(b)

FIGURE 2: TEM images of MWCNT-Nafion nanocomposites before (a) and after (b) electrodeposition of PtRu nanoparticles.

images of MWCNT-Nafion nanocomposite before and after electrodeposition of the PtRu nanoparticles. In Figure 2(b), it can be seen that PtRu nanoparticles were deposited in the MWCNT-Nafion nanocomposite with a diameter of $10-20 \mathrm{~nm}$. The formation of $\mathrm{PtRu}$ nanoparticles within the MWCNT-Nafion nanocomposite is supported by EDS observation. Figure 3 shows the EDS patterns of MWCNTNafion nanocomposite before and after electrodeposition of $\mathrm{PtRu}$ nanoparticles. Figure 3(a) indicates that the $\mathrm{C}, \mathrm{O}$, and $\mathrm{F}$ were the major elements before electrodeposition. The $\mathrm{C}$ signal came from the MWCNTs and Nafion; O and $\mathrm{F}$ were derived from Nafion. In Figure $3(\mathrm{~b})$, the $\mathrm{Pt}$ and $\mathrm{Ru}$ elements can be seen after the electrodeposition of $\mathrm{PtRu}$ nanoparticles. Thus, we can conclude that the PtRu nanoparticles are indeed coelectrodeposited in the MWCNTNafion nanocomposite.

3.2. Effect of the Atomic Ratio of Pt : Ru on the Electrocatalytic Ability towards the Methanol Electrooxidation. In order to investigate the effect of the atomic composition of $\mathrm{PtRu}$ on the electrocatalytic ability towards the electrochemical oxidation of methanol, the PtRu-MWCNTNafion nanocomposite-modified glassy carbon electrodes prepared with different atomic ratio of $\mathrm{Pt}: \mathrm{Ru}$ were characterized by cyclic voltammetry in $2 \mathrm{M} \mathrm{CH} 3 \mathrm{OH}+1 \mathrm{M}$

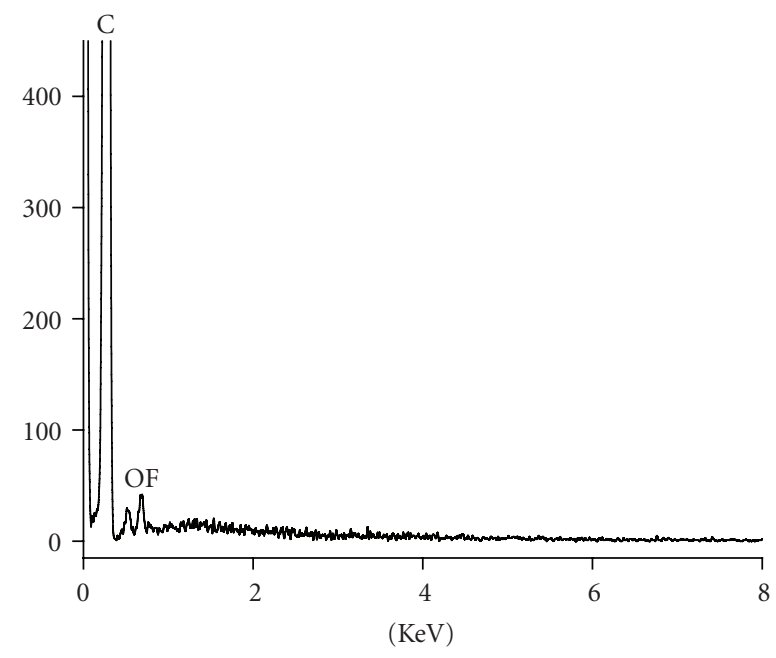

(a)

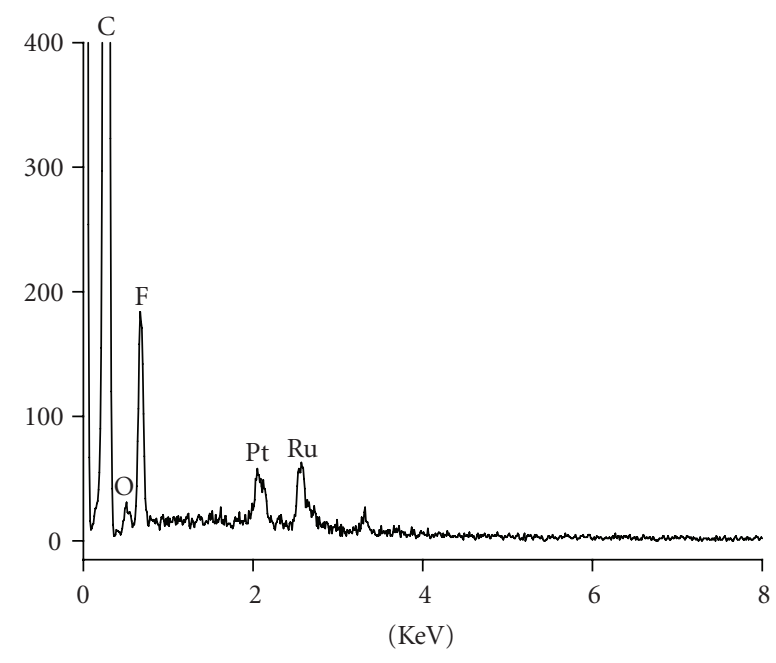

(b)

FIGURE 3: EDS patterns of MWCNT-Nafion nanocomposite before (a) and after (a) electrodeposition of PtRu nanoparticles.

$\mathrm{H}_{2} \mathrm{SO}_{4}$. Figure 4 shows the cyclic voltammograms recorded for the Pt-MWCNT-Nafion (Figure 4(a)), $\operatorname{PtRu}(2.3: 1$ )MWCNT-Nafion (Figure 4(b)), PtRu(1 : 1)-MWCNTNafion (Figure 4(c)), and PtRu(1 : 2.1)-MWCNT-Nafion (Figure 4(d)) nanocomposite-modified glassy carbon electrodes in $2 \mathrm{M} \mathrm{CH}_{3} \mathrm{OH}+1 \mathrm{M} \mathrm{H}_{2} \mathrm{SO}_{4}$ at a scan rate of $50 \mathrm{mV} \mathrm{s}^{-1}$ at cycle 5 . Two peaks of methanol oxidation could be observed at Pt-MWCNT-Nafion-modified glassy carbon electrode (Figure 4(a)). The peak potentials were 0.669 and $0.513 \mathrm{~V}$ for the forward and backward scans, respectively. The forward anodic peak represented that the methanol was oxidized to carbon dioxide, and the reverse anodic peak resulted from the accumulation of carbonaceous species [1]. It can be seen in Figure 4 that the PtRu-MWCNT-Nafionmodified electrode exhibited a substantial negative shift of the forward anodic peak when the atomic composition of $\mathrm{PtRu}$ is changed from pure $\mathrm{Pt}$ to PtRu binary catalyst. The electrocatalytic oxidation is evident from the forward anodic 


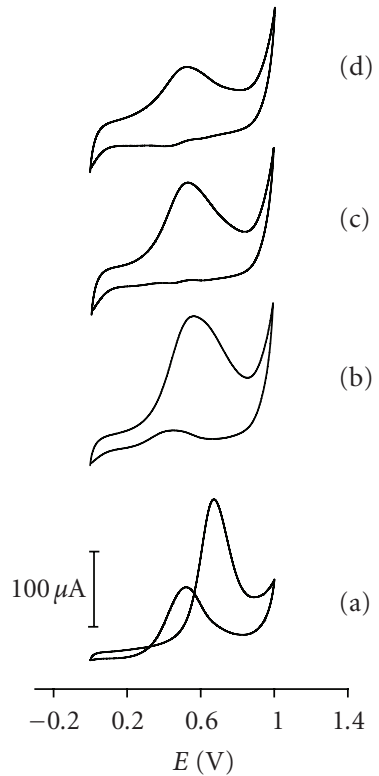

Figure 4: Cyclic voltammograms of the Pt-MWCNT-Nafion (a), $\operatorname{PtRu}(2.3$ : 1)-MWCNT-Nafion (b), $\operatorname{PtRu}(1: 1)-$ MWCNT-Nafion (c), and $\operatorname{PtRu}(1$ : 2.1)-MWCNT-Nafion (d) nanocompositemodified glassy carbon electrodes in $2 \mathrm{M} \mathrm{CH}_{3} \mathrm{OH}+1 \mathrm{M} \mathrm{H}_{2} \mathrm{SO}_{4}$ at a scan rate of $50 \mathrm{mV} \mathrm{s}^{-1}$ at cycle 5 .

peak potentials of methanol which are 0.522 and $0.669 \mathrm{~V}$ for $\operatorname{PtRu}(1: 1)$-MWCNT-Nafion and Pt-MWCNT-Nafionmodified electrodes, respectively. Further evidence of electrocatalytic ability at PtRu-MWCNT-Nafion nanocomposite can be observed from the ratio of the forward anodic peak current $\left(\mathrm{I}_{\mathrm{f}}\right)$ to the backward anodic peak current $\left(\mathrm{I}_{\mathrm{b}}\right)$. The $\mathrm{I}_{\mathrm{f}} / \mathrm{I}_{\mathrm{b}}$ value shows the catalyst tolerance to accumulation of carbonaceous species [15]. From Figure 4 , the $\mathrm{I}_{\mathrm{f}} / \mathrm{I}_{\mathrm{b}}$ values are 2.02, 6.55, 447.06, and 52.37 for the Pt-MWCNT-Nafion, $\operatorname{PtRu}(2.3$ : 1)-MWCNT-Nafion, $\operatorname{PtRu}(1:$ 1)-MWCNTNafion, and $\mathrm{PtRu}(1: 2.1)$-MWCNT-Nafion nanocompositemodified glassy carbon electrodes, respectively. High $\mathrm{I}_{\mathrm{f}} / \mathrm{I}_{\mathrm{b}}$ value obtained at $\operatorname{PtRu}(1: 1)$-MWCNT-Nafion-modified glassy carbon electrode indicated that most of the intermediate carbonaceous species were oxidized to carbon dioxide in the forward scan at the $\operatorname{PtRu}(1: 1)$-MWCNT-Nafionmodified glassy carbon electrode. The optimal atomic ratio of $\operatorname{PtRu}(1: 1)$ obtained in this study for direct methanol fuel cell is close to the previous report [2]. The improvement of methanol electrooxidation at the $\operatorname{PtRu}(1: 1)$-MWCNTNafion-modified electrode is attributed to the oxygenated species provided by $\mathrm{Ru}$ in the vicinity of Pt sites, which create additional active sites for $\mathrm{CO}_{\mathrm{ads}}$ oxidation [25].

3.3. Electrochemical Impedance Spectroscopy Studies of the PtRu-MWCNT-Nafion Nanocomposite-Modified Glassy Carbon Electrode. Electrochemical impedance spectroscopy was employed to investigate the methanol electrooxidation at PtRu-MWCNT-Nafion-modified glassy carbon electrode because it is a powerful technique to study the interface processes of modified electrodes. For comparison, a control

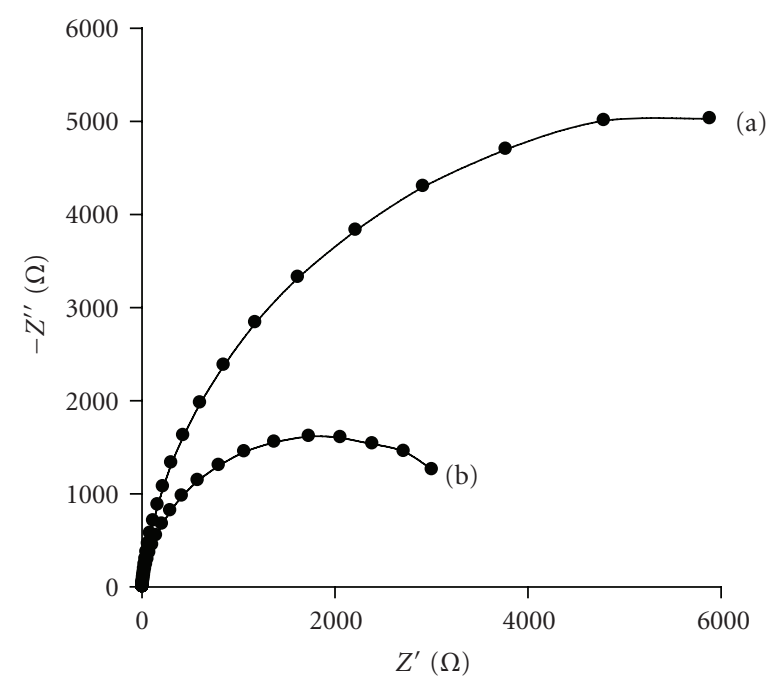

FIgure 5: Nyquist plots of the Pt-MWCNT-Nafion (a) and PtRu(1 : 1)-MWCNT-Nafion (b) nanocomposite-modified glassy carbon electrodes in $2 \mathrm{M} \mathrm{CH}_{3} \mathrm{OH}+1 \mathrm{M} \mathrm{H}_{2} \mathrm{SO}_{4}$ at an applied potential of $0.6 \mathrm{~V}$ versus $\mathrm{Ag} / \mathrm{AgCl}$.

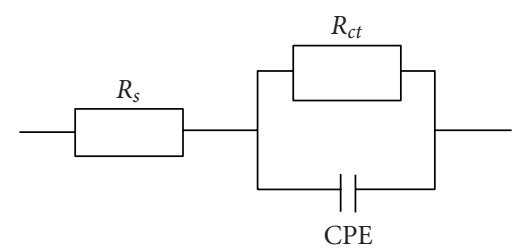

Figure 6: Equivalent circuit used to fit the impedance spectra presented in Figure 5.

experiment at the Pt-MWCNT-Nafion nanocompositemodified glassy carbon electrode was also carried out. Figure 5 shows the Nyquist plots of Pt-MWCNT-Nafion and $\operatorname{PtRu}(1: 1)$-MWCNT-Nafion nanocomposite-modified glassy carbon electrodes in $2 \mathrm{M} \mathrm{CH}_{3} \mathrm{OH}+1 \mathrm{M} \mathrm{H}_{2} \mathrm{SO}_{4}$ solution at a working potential of $0.6 \mathrm{~V}$. The ac impedance spectrum was recorded in the frequency range $0.01-10000 \mathrm{~Hz}$. Figure 6 shows the equivalent circuits used to simulate the impedance response. In Figure 6, $R_{s}$ represents the solution resistance, $R_{c t}$ the charge transfer resistance associated with methanol electrooxidation, and CPE the constant phase element associated with the double layer capacitance [15]. In Figure 5, the real axis intercept at high frequency was found to be independent of electrodes and corresponds to the uncompensated resistance of the bulk electrolyte solution $\left(R_{s}\right)$. The $R_{c t}$ which controls the electron transfer kinetics of electroactive species at the electrode interface can be estimated from the diameter of the semicircle at higher frequencies. The $\mathrm{R}_{\mathrm{ct}}$ of the $\operatorname{PtRu}(1: 1)$-MWCNT-Nafionmodified glassy carbon electrode $(3.72 \mathrm{~K} \Omega$ ) was smaller than that of Pt-MWCNT-Nafion-modified glassy carbon electrode $(11.4 \mathrm{~K} \Omega)$, indicating that the higher electrocatalytic activity towards the methanol electrooxidation was obtained at $\operatorname{PtRu}(1: 1)$-MWCNT-Nafion-modified glassy carbon 


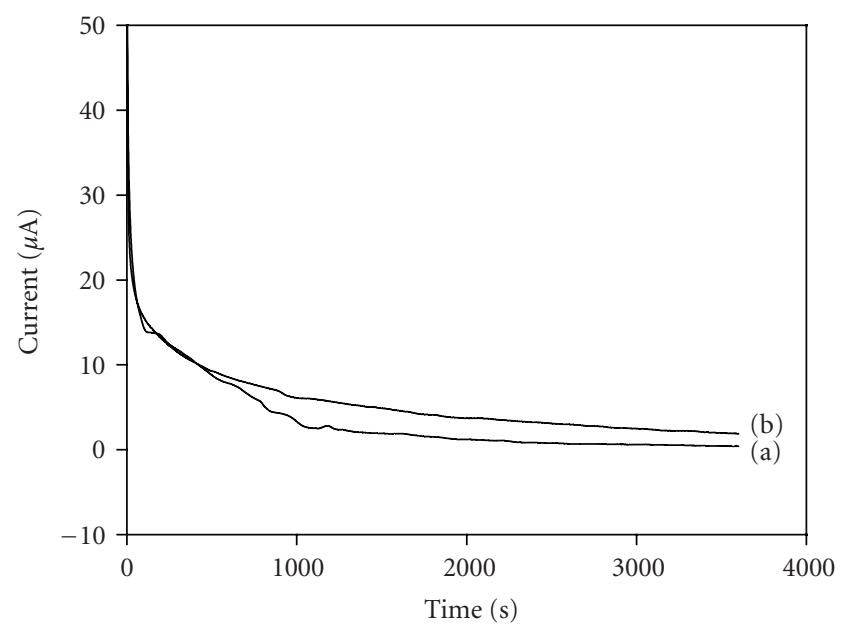

Figure 7: Current-time curves for the Pt-MWCNT-Nafion (a) and $\operatorname{PtRu}(1: 1)$-MWCNT-Nafion nanocomposite-modified glassy carbon electrodes in $2 \mathrm{M} \mathrm{CH}_{3} \mathrm{OH}+1 \mathrm{M} \mathrm{H}_{2} \mathrm{SO}_{4}$ at an applied potential of $0.6 \mathrm{~V}$ versus $\mathrm{Ag} / \mathrm{AgCl}$.

electrode. This result is in accordance with the voltammetric responses of Figure 4.

3.4. Stability of the PtRu-MWCNT-Nafion NanocompositeModified Glassy Carbon Electrode. The stability of the electrocatalyst towards the methanol electrooxidation is crucial for practical applications. To investigate the stability of the PtRu(1 : 1)-MWCNT-Nafion and Pt-MWCNT-Nafion nanocomposite-modified electrodes to methanol electrooxidation, chronoamperometry was performed. Figure 7 shows the chronoamperometry curves for the $\operatorname{PtRu}(1: 1)$ MWCNT-Nafion and Pt-MWCNT-Nafion nanocompositemodified glassy carbon electrodes in $2 \mathrm{M} \mathrm{CH} \mathrm{CH}_{3} \mathrm{OH}+1 \mathrm{M}$ $\mathrm{H}_{2} \mathrm{SO}_{4}$ at an applied potential of $0.6 \mathrm{~V}$. The current responses decreased sharply in the initial period of time at both the $\operatorname{PtRu}(1$ : 1)-MWCNT-Nafion and Pt-MWCNTNafion nanocomposite-modified electrodes. This might be attributed to the formation of intermediate species such as $\mathrm{CO}_{\mathrm{ads}}$ during the methanol electrooxidation at the electrodes. The current response was higher at $\operatorname{PtRu}(1: 1)$ MWCNT-Nafion nanocomposite-modified electrode than that of Pt-MWCNT-Nafion nanocomposite-modified electrode after 3600 seconds. This indicates that the inclusion of $\mathrm{Ru}$ in PtRu-MWCNT-Nafion nanocomposite is able to alleviate surface passivation during the electrochemical oxidation of methanol. The higher electrocatalytic activity observed at PtRu(1 : 1)-MWCNT-Nafion nanocompositemodified electrode is ascribed to that the $\mathrm{Ru}$ promotes the oxidation of the strongly bound $\mathrm{CO}_{\mathrm{ads}}$ on Pt by supplying an oxygen source in the form of $\mathrm{Ru}-\mathrm{OH}_{\mathrm{ads}}$.

\section{Conclusion}

In this work we have demonstrated that PtRu nanoparticles with a diameter of 10-20 nm can be deposited in MWCNTNafion nanocomposite by an electroreduction method. It indicates that MWCNTs are good candidates for catalyst support because of their high surface-to-volume ratio. The resulting PtRu-MWCNT-Nafion nanocomposite is active for the electrochemical oxidation of methanol, which is oxidized at a lower potential than that of Pt-MWCNTNafion nanocomposite. The $\operatorname{PtRu}(1: 1)$-MWCNT-Nafion nanocomposites show a higher $\mathrm{I}_{\mathrm{f}} / \mathrm{I}_{\mathrm{b}}$ value and a better stability than that of Pt-MWCNT-Nafion nanocomposites. This might be attributed to the bifunctional mechanism of $\mathrm{Ru}$ to $\mathrm{Pt}$. It should be emphasized that the catalysts amount in the MWCNT-Nafion nanocomposite is also important for the preparation of methanol electrooxidation catalysts. The results presented in this paper demonstrate that the coelectrodeposition of PtRu in MWCNT-Nafion nanocomposite has a promising potential application in preparing bimetallic electrocatalysts for the development of direct methanol fuel cell.

\section{Acknowledgments}

The authors wish to thank the National Science Council, Taiwan, for financial support. This work is supported in part by the Ministry of Education, Taiwan, under the ATU plan.

\section{References}

[1] A. S. Aricò, S. Srinivasan, and V. Antonucci, "DMFCs: from fundamental aspects to technology development," Fuel Cells, vol. 1, no. 2, pp. 133-161, 2001.

[2] Z. Liu, X. Y. Ling, X. Su, and J. Y. Lee, “Carbon-supported Pt and PtRu nanoparticles as catalysts for a direct methanol fuel cell," The Journal of Physical Chemistry B, vol. 108, no. 24, pp. 8234-8240, 2004.

[3] M. J. González, C. H. Peters, and M. S. Wrighton, "PtSn microfabricated surfaces as catalysts for organic electrooxidation," The Journal of Physical Chemistry B, vol. 105, no. 23, pp. 5470-5476, 2001.

[4] J. T. Moore, D. Chu, R. Jiang, G. A. Deluga, and C. M. Lukehart, "Synthesis and characterization of Os and PtOs/carbon nanocomposites and their relative performance as methanol electrooxidation catalysts," Chemistry of Materials, vol. 15, no. 5, pp. 1119-1124, 2003.

[5] F. Liu, J. Y. Lee, and W. Zhou, "Template preparation of multisegment $\mathrm{PtNi}$ nanorods as methanol electro-oxidation catalysts with adjustable bimetallic pair sites," The Journal of Physical Chemistry B, vol. 108, no. 46, pp. 17959-17963, 2004.

[6] K.-Y. Chan, J. Ding, J. Ren, S. Cheng, and K. Y. Tsang, "Supported mixed metal nanoparticles as electrocatalysts in low temperature fuel cells," Journal of Materials Chemistry, vol. 14, no. 4, pp. 505-516, 2004.

[7] D. M. Dotzauer, J. Dai, L. Sun, and M. L. Bruening, "Catalytic membranes prepared using layer-by-layer adsorption of polyelectrolyte/metal nanoparticle films in porous supports," Nano Letters, vol. 6, no. 10, pp. 2268-2272, 2006.

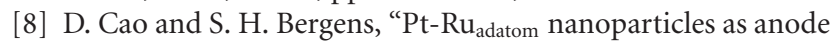
catalysts for direct methanol fuel cells," Journal of Power Sources, vol. 134, no. 2, pp. 170-180, 2004.

[9] K.-W. Park, D.-S. Han, and Y.-E. Sung, "PtRh alloy nanoparticle electrocatalysts for oxygen reduction for use in direct methanol fuel cells," Journal of Power Sources, vol. 163, no. 1, pp. 82-86, 2006. 
[10] Y. Liu, J. Chen, W. Zhang, et al., "Nano-Pt modified aligned carbon nanotube arrays are efficient, robust, high surface area electrocatalysts," Chemistry of Materials, vol. 20, no. 8, pp. 2603-2605, 2008.

[11] M. Chikae, K. Idegami, K. Kerman, et al., "Direct fabrication of catalytic metal nanoparticles onto the surface of a screenprinted carbon electrode," Electrochemistry Communications, vol. 8, no. 8, pp. 1375-1380, 2006.

[12] Z. Wang and K. Qiu, "Electrocatalytic oxidation of formic acid on platinum nanoparticle electrode deposited on the nichrome substrate," Electrochemistry Communications, vol. 8, no. 7, pp. 1075-1081, 2006.

[13] B. Yang, Q. Lu, Y. Wang, et al., "Simple and low-cost preparation method for highly dispersed PtRu/C catalysts," Chemistry of Materials, vol. 15, no. 18, pp. 3552-3557, 2003.

[14] T. J. Schmidt, M. Noeske, H. A. Gasteiger, R. J. Behm, P. Britz, and H. Bönnemann, "PtRu alloy colloids as precursors for fuel cell catalysts: a combined XPS, AFM, HRTEM, and RDE study," Journal of the Electrochemical Society, vol. 145, no. 3, pp. 925-931, 1998.

[15] Y. Lin, X. Cui, C. H. Yen, and C. M. Wai, "PtRu/carbon nanotube nanocomposite synthesized in supercritical fluid: a novel electrocatalyst for direct methanol fuel cells," Langmuir, vol. 21, no. 24, pp. 11474-11479, 2005.

[16] M. Mastragostino, A. Missiroli, and F. Soavi, "Carbon supports for electrodeposited Pt-Ru catalysts for DMFCs," Journal of the Electrochemical Society, vol. 151, no. 11, pp. A1919A1924, 2004.

[17] G. G. Wildgoose, C. E. Banks, and R. G. Compton, "Metal nanoparticles and related materials supported on carbon nanotubes: methods and applications," Small, vol. 2, no. 2, pp. 182-193, 2006.

[18] M. Carmo, V. A. Paganin, J. M. Rosolen, and E. R. Gonzalez, "Alternative supports for the preparation of catalysts for lowtemperature fuel cells: the use of carbon nanotubes," Journal of Power Sources, vol. 142, no. 1-2, pp. 169-176, 2005.

[19] M. Okamoto, T. Fujigaya, and N. Nakashima, "Design of an assembly of poly(benzimidazole), carbon nanotubes, and Pt nanoparticles for a fuel-cell electrocatalyst with an ideal interfacial nanostructure," Small, vol. 5, no. 6, pp. 735-740, 2009.

[20] X. Wang, W. Li, Z. Chen, M. Waje, and Y. Yan, "Durability investigation of carbon nanotube as catalyst support for proton exchange membrane fuel cell," Journal of Power Sources, vol. 158, no. 1, pp. 154-159, 2006.

[21] R. P. Deo and J. Wang, "Electrochemical detection of carbohydrates at carbon-nanotube modified glassy-carbon electrodes," Electrochemistry Communications, vol. 6, no. 3, pp. 284-287, 2004.

[22] Y.-C. Tsai, J.-M. Chen, S.-C. Li, and F. Marken, "Electroanalytical thin film electrodes based on a Nafion ${ }^{\mathrm{TM}}$ multi-walled carbon nanotube composite," Electrochemistry Communications, vol. 6, no. 9, pp. 917-922, 2004.

[23] H.-W. Liaw, J.-M. Chen, and Y.-C. Tsai, "Development of an amperometric ethanol biosensor based on a multiwalled carbon nanotube-Nafion-alcohol dehydrogenase nanobiocomposite," Journal of Nanoscience and Nanotechnology, vol. 6, no. 8, pp. 2396-2402, 2006.

[24] Y. Cheng, Y. Liu, J. Huang, et al., "Rapid amperometric detection of coliforms based on MWNTs/Nafion composite film modified glass carbon electrode," Talanta, vol. 75 , no. 1 , pp. 167-171, 2008.

[25] D. R. Rolison, P. L. Hagans, K. E. Swider, and J. W. Long, "Role of hydrous ruthenium oxide in Pt-Ru direct methanol fuel cell anode electrocatalysts: the importance of mixed electron/proton conductivity," Langmuir, vol. 15, no. 3, pp. 774-779, 1999. 

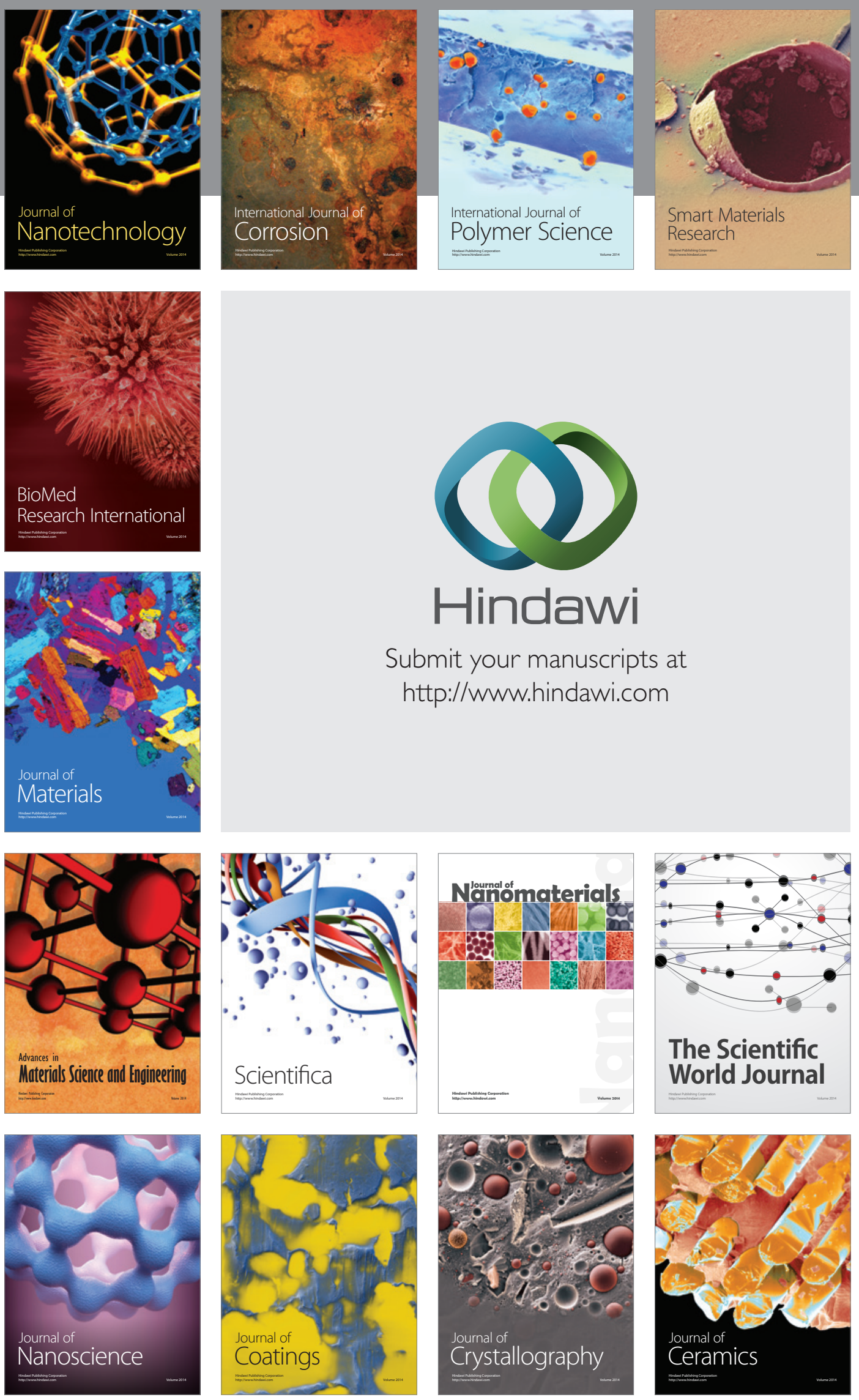

The Scientific World Journal

Submit your manuscripts at

http://www.hindawi.com

\section{World Journal}

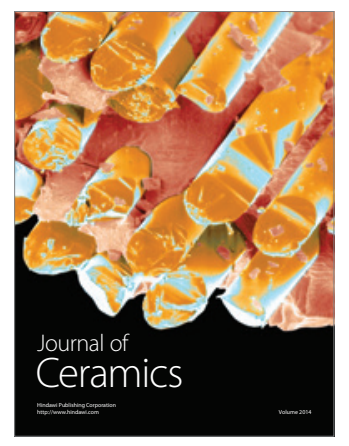

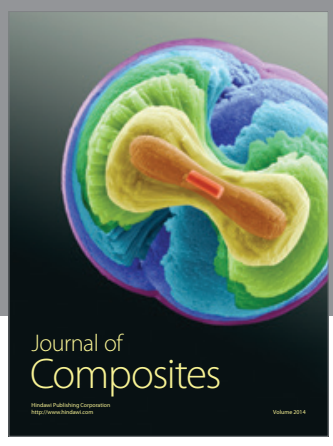
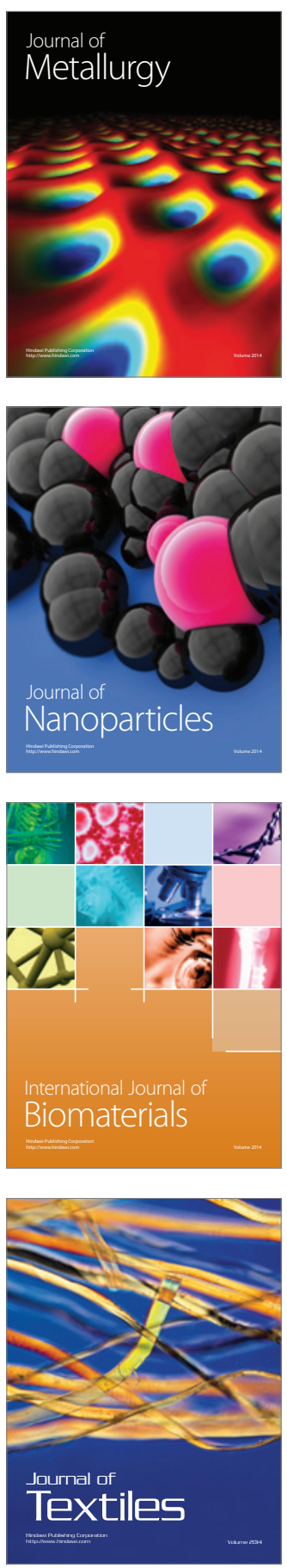